\title{
Upcycling: Beautifying Old-Fashioned Clothes in Indonesia
}

\author{
Ratna Suhartini, Juhrah Singke, Dwi Yanti \\ Department of Home Economics \\ Universitas Negeri Surabaya \\ Surabaya, Indonesia \\ ratnasuhartini@unesa.ac.id
}

\begin{abstract}
This study aimed to improve old clothes' using an upcycle technique through redesigning, combining, and decorating. The study was broken up into three stages: exploration, design, and embodiment. Thirty new fashion designs for blouses and skirts were first categorized into three types (redesigning, combining and decorating design); these were then assessed by 30 fashion design experts. Results showed that all experts gave good scores for each category. Further, this study recommends an alternative way to redesign clothing in order to limit waste.
\end{abstract}

Keywords - upcycle technique; redesigning; combining; decorating

\section{INTRODUCTION}

Clothes is primary need for humans. The clothing need will continue to increase as the world population grows. A lot of ongoing trading activities make Indonesian economy increase. Consumer do not buy clothes continuously, sometimes they buy a lot of secondhand import clothes or local clothes on a lot of place as markets or malls that sell second hand clothes.It raises question "why do consumer still often buy new clothes or secondhand clothes, the specificity of the secondhand clothing economy has much to offer contemporary theoretical concerns with economization, marketization, and the convergence of economic value with cultural values[1]. although in the reality they still have clothes that can still be used. clothing trade is a global phenomenon that transcends national boundaries, used clothing traders, retailers, and consumers unite in challenging the beliefs driven by institutions that regulate and compete with this trade[2].Many reason of consumerto buy new clothes or secondhand clothes". According to [3]students buy secondhand clothes have some behavior.As follow,they will pay attention to time and place because they will be ashamed if it can be seen by their friends, family or neighbors who can affect their social status in society, They want to buy clothes because they want to describe himself and their organization, or influence from advertising, western culture, and the campus culture. According to[4], factors that influence the pattern of shopping for secondhand clothes buyer are family's background, parent jobs, and the place of shopping. It gives benefits for poor people. upcycled fashion design and production processes, in order to aid the development of large-scale fashion upcycling in the UK, and contribute to a circular economy[5].

Wrap organization in United Kingdom that focus on the reduction of water use and waste treatment, especially garment and household waste optimally. The organization said that in 2011 the reality of 10 percent to 20 percent of clothing on the market has expired during its lifetime or it is time to be discarded. Meanwhile, to produce 1 kilogram of cotton requires 20,000 liters of water. It can be concluded and predicted the number of new clothes that are always produced every day, and the amount of water wasted, and the amount of waste generated.students learn with garments and textile refuse when engaging in a remake project. The exploration is conducted in a Swedish crafts class, educational solid, as a case. Practical epistemological analysis and the concept of transact ant are used to analyses and be attentive to the learning process. The findings show how students transact[6].

The issues above can solve by upcycle innovation for the clothes. The process is opposite of down cycling processthat recycling of product to be product with better value than before. For example, clothes did not use because some factorsas the model is not up to date. The research builds on a design project with a social firm where obsolete textiles from corporate uniforms are redesigned into children's apparel. With theupcycleprocess, the clothes that no up to date can be up to date.New textile recycling technologies have the potential to redirect material resource flows, disrupt global secondary markets and reconfigure the waste hierarchy [7].

This research was conducted to treat the waste without producing new waste or reduce the quantity of waste generated. The expectation of upcycle method on used clothes are to increase the life of second-hand clothes, can increase the economic value, fungsional and aesthetics.Based on the issue above, the researchers conducted research on the creation of "Upcycle: environmentally friendly". This study is to determine the process of designing and techniques or methods of upcycle on used clothing as a waste-waste used clothing. The research benefits for the fashion Industry adds innovation to make waste used to reduce waste of used clothing produced by some clothing industries. Upcycle is recycling fashion products into products that have better value than previous 
products. Casual clothing is a fashion that has a dynamic structure and looks relaxed. Used clothing is clothing that is no longer used because of several factors.

According to[8]before the formation of waste should be carried out actions that are oriented to minimize the occurrence of waste that can be done through raw material selection, process engineering and application of reuse, recycle and recovery principles. Secondhand clothes is clothes that have been used by others [3]. This used some clothing in the waste just like that to pile up in the landfill, some more in the imports then traded back to the community at a low price. One way is to do upcycling a waste of clothing or clothing that is not used anymore because the model is not up to date or fashion is not able to be used because of human growth factor is very rapidly, a new fashion with up to date model and can be empowered Use. The steps carried out during the year-long project demonstrated that almost $40 \%$ of used clothing waste could be repurposed as new clothing and the remaining waste could be processed further for additional use in non-apparel applications [9].

According to[10], states that design for upcycling is about 'not merely conserving the resourcesthat went into the production of particular materials, but adding to the value embodied in them by the application of knowledge in the course of their recirculation' In contrast to reusing or recycling, upcycling uses existing materials to improve upon the original ones. The process requires a considerable amount of creativity and vision, as well as a foundation of thriftiness and environmental consciousness design.From the understanding above, upcycling is adding value contained in it with the application of knowledge in the course of recirculation. In contrast to reuse or recycle, upcycling uses existing materials to repair the original. This process requires quite a lot of creativity and vision, as well as the foundation of thriftiness and environmental awareness. The end result is a product or item, handmade, and sustainable and costeffective.eco-wedding dresses and analyses consumers' attitudes on such dresses, providing alternative design practices for wedding dresses and ways to encourage the use of eco-wedding dresses. Through a literature review and online search of relevant brands, six types of eco-wedding dress were identified: those made of eco-friendly materials; made of pre- or post-consumer waste; made with less material and waste; convertible; previously worn; and altered for reuse. Research on eco-wedding dress types and the consumer survey of 198 Korean females revealed low awareness, dissatisfaction with design and price, and insufficient information on sustainability[11].

Upcycling is the process of creating something new from old products, waste materials, and unwanted products and better quality materials and for better environmental values. The term often used, 'recycled', is the process of 'downcycling' (waste reduction) into reusable products while on the other hand, 'upcycling', a particular form of recycling, involves changing waste materials or unwanted products Into a better quality product [12].Some companies seek to create their products in a more eco-friendly way to meet the demands of environmentally conscious consumers. So, if one can add economic value, intellectual, emotional, material to the product through the reuse process, it can be called 'upcycled'[13]. Redesign could vary by the extent of the garment's change, from adding minor design details such as a decorative trim, to changes of the garment's silhouette such as adding a peplum, and to complete transformation of the garment's original purpose such as changing from a dress to a top[14].

Upcycle can be applied to a used clothing with merging of 2 types of clothing and change of clothing model and addition of other material. Upcycle does not require any special method or formula to do so, such as Michelle Paganini's Designer's statement in an article in the upcycling in the Threads magazine in February 2015, she states that "advantage for upcycling is no need to sew bits like collars, armholes, front plackets, and buttonholes, as the existing features are kept from the starting garments. "When producing garments utilizing zero-waste pattern cutting methods, it can be seen that the design and make process has to be transformed in order to create garment designs, both desirable and achievable[15].

Up cycling is the process of creating something new from old products, waste materials, and unwanted products and better quality materials and for better environmental values [12]. To produce a good clothing affected by fashion design which must be considered from the technique of fashion design that is made of design elements and design principles. The elements and principles of design according to [16]ie design elements include: lines and direction, shape, size. The design principles include: alignment, proportion, balance, rhythm, accent. According to Anderson in[17] the design principles are generally divided into three groups, namely: synthesizing, unity, linear, highlighting.

\section{METHOD}

The description research about Upcycling: Beautifying old fashion clothes in Indonesia. The research design is a design designed to avoid deviations that occur during data collection. The research design in this study is described as follows

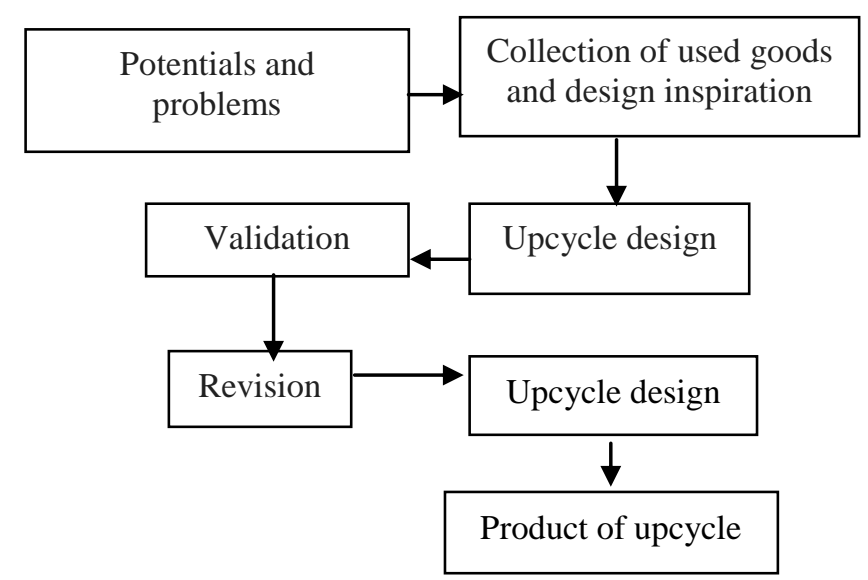

Fig. 1. Research design 
Research strategy in the implementation of this research are as follows: Collect 9 design inspirations

$$
\bullet
$$

\section{decoration}

Upcycle merging 2 clothes

Upcycle clothing change model

Upcycle addition of material or

Data analysis was done in two ways, namely pre upcycle and post upcycle. In the pre-creation calculation of data that has been collected to determine the average value and percentage of which design is best to be realized which then arranged systematically. Method of data analysis using percentage.

\section{RESULT AND DISCUSSION}

Upcycle merging of two outfits (Upcycle 1, Upcycle 2, and Upcycle 3)

A. The result of the research data obtained the acquisition result mean 3.60 upcycle I and II, upcycle III 3.35 this thing on design aspect (application of element and design principle included in good category, design analysis made and finished secondhand clothing in-upcycle in accordance with the four points that have been described are: The proportion of design and finished products are appropriate and not excessive (ex: proportion of decoration, cutting, model), Center of interest is found in upcome [16] states that in a fashion design there should be a section that is more interesting than the other so-called center of interest.Color or pattern used to create the impression harmonious.Color matching color in clothing should be considered, because the use of color is very important in supporting the appearance of a fashion [17].The result so upcycle has Compatibility with the element of aesthetic value (beauty) The clothes that combine aesthetic values and creative elements can also be appearance and social status of a person [18].

B.

The results of research data obtained the acquisition results mean 3.84 upcycle I and 3.6 upcycle 2 and 3.53 for upcycle 3 . Upcycle process has passed the appropriate stages) included in the category of either close to perfect. Can be interpreted that the upcycle process described by the image and words can be understood by the observer, as well as the steps are clearly arranged and can be understood in accordance with the 4 points that have been described are:

Preparing tools and materials to
- upcycle used clothing,
Mark the pattern on the part to be in
- upcycle,
Cut clothes to be in upcycle according
- to the pattern mark
Sew clothes to be in upcycle

Stages of the process of upding clothing is in accordance with the steps of making clothes or clothing in general, but at the stage of making clothes upcycle no stage of making the pattern due to this stage is replaced with a direct sign pattern on the clothes that will be in the upcycle. Stages of this stage there is no theory that really states that the correct stages are like the statement above but the stages of the stage can facilitate the observer in observing the process of upcycle used clothing.

C. The results of research data obtained the acquisition of the mean 3.88 upcycle I, 3.84 upcycle II and 3.52 upcycle III Aspects of waste utilization (used clothing) included in either category. Can be interpreted that the utilization of waste (used clothing) on the upcycle is in accordance with the 4 points that have been described are:

- $\quad$ Before the formation of waste, carried out actions that are oriented on efforts to minimize the occurrence of textile waste that is to uptime the clothes. According to[8]before the formation of waste, action-oriented measures to minimize the occurrence of waste that can be done through raw material selection, process engineering and application of reuse, recycle and recovery principles.

Used clothing with out of date models can be uplined to be up to date fashion back. Namely the new Upcycling of old products, waste materials, and unwanted products and better quality materials and for better environmental value[12].

- Used clothing that is thrown away so as to accumulate in the landfill, can be minimized by uptime personal clothing to upgrade. Clothes can be upgraded not by buying new clothes and throwing away old ones, but can be upgraded by uptime wearing clothes into new clothes. The statement concerning used clothing is stockpiled and ends up in the landfill and some are imported and purchased [3]reinforced by the statement of M. [8]that prior to the formation of waste should be action oriented efforts to minimize the occurrence of waste that can be done through raw material selection, process engineering and application of the principle of reuse, recycle and recovery.

The process of utilizing waste used clothing requires quite a lot of creativity and vision and grounding thriftiness and environmental awareness. [10]this up-going process requires high creativity to utilize and create new ideas in processing a waste and the results that have been obtained in this point in both good and perfect categories.

sentence: "Equation (1) is ..."

D. The results of the research data obtained the acquisition of mean 3.72 upcycle I, 3.64 upcycle II and 3.42 upcycle III. this is on the aspect of Upcycle So the results are included in either category. Can be interpreted that the results so upcycle used clothing in accordance with the four points that have been translated are: 1 . The result is clothing in upcycle in accordance with the design / inspiration of the design, 2. The results are the clothes in the upcycle unique and inspiring, 3 . The results so that the clothes on the upcycle including casual dress up to date. The results so clothes on the upcycle can be used as everyday clothes.

\section{CONCLUSION}

Based on the research results can be summarized as follows. There are three techniques used upcycle that is 
combining, changing the model and decorate used clothing that will be described as follows:

\section{A. Combine 2 outfits}

Upcycle process gets good category average results. Utilization of waste generated good category Result so clothing category good, where the result so acceptable.

B. Changed the clothing model

Upcycle process get good category results Utilization of this waste generated good category. The result so clothing got good category, the result so acceptable.

\section{Addition of other materials / ornaments}

Upcycle process gets good category results. Utilization of this waste generated good category Result so clothing got score in good category, result so acceptable.

\section{REFERENCES}

[1] Redesigning Fashion: An Analysis And Categorization Of Women's Clothing Upcycling Behavior. Janigo, Kristy A, Wu, Juanjuan And Delong, Marilyn. 2, 2017, Journal Fashion Practice The Journal Of Design, Creative Process \& The Fashion Industry, Vol. 9, Pp. 254-279.

[2] Investigating Second-Hand Fashion Trade And Consumption In The Philippines: Expanding Existing Discourses. Isla, Veronica L. 3, 2013, Journal Of Consumer Culture, Vol. 13, Pp. 221-240.

[3] Perilaku Konsumen Pakaian Bekas (Studi Pada Perilaku Konsumen Mahasiswa Dalam Membeli Pakaian Bekas Di Kota Gorontalo). Ingo, Rahman, Rahmatiah And Harold, Rudy. 2015.

[4] Fenomenologi Gaya Hidup Mahasiswa Unesa Pengguna Pakaian Bekas. Dwiyantoro, Arik And Harianto, Sugeng. 3, 2013, Jurnal Paradigma, Vol. 2.

[5] Standard Vs. Upcycled Fashion Design And Production. Han, Sara L C, Et Al. 1, 2016, Journal Fashion Practice: The Journal Of Design, Creative Process \& The Fashion Industry, Vol. 9, Pp. 69-84.

[6] Recycling, Crafting And Learning - An Empirical Analysis Of How Students Learn With Garments And Textile Refuse In A School Remake
Project. Hofverberg, Hanna And Maivorsdotter, Ninitha. 2016, Journal Environmental Education Research, Pp. 1-16.

[7] Urban Prototypes: Growing Local Circular Cloth Economies. Norris, Lucy. 2017, Journal Business History, Pp. 1-20.

[8] Strategi Pengelolaan Limbah Radioaktif Di Indonesia Ditinjau Dari Konsep Cradle To Grave. Alfiyan, Mokhammad And Akhmad, Yus Rusdian. 2, 2010, Jurnal Teknologi Pengelolaan Limbah, Vol. 13, Pp. 29-36.

[9] Closing The Loop: A Scalable Zero-Waste Model For Apparel Reuse And Recycling. Lewis, Tasha L, Et Al. 3, 2017, Journal International Journal Of Fashion Design, Technology And Education, Vol. 10, Pp. 353-362.

[10] Murray, Robin.Zero Waste. London : Greenpeace Environmental Trust, 2002.

[11] Green Can Be The New White For Wedding Dresses. Kwon, Sang Hee. 5, 2017, The Design Journal: An International Journal For All Aspects Of Design, Vol. 20, Pp. 595-616.

[12] A Study Of High Value-Added Upcycled Handbag Design For The Dubai Luxury Fashion Market. Kim, Hyun Joo. 1, 2014, Journal Of The Korean Society Of Fashion Design, Vol. 14, Pp. 173-188.

[13] Modi, Darshita.Upcycling Fabric Waste In Design Studio. Mumbai : National Institute Of Fashion Technology , 2013.

[14] Collaborative Redesign Of Used Clothes As A Sustainable Fashion Solution And Potential Business Opportunity. Janigo, Kristy A And Wu, Juanjuan. 1, 2015, Journal Fashion Practice, Vol. 7, Pp. 75-98.

[15] Transforming The Sequential Process Of Fashion Production: Where Zero-Waste Pattern Cutting Takes The Lead In Creative Design. James, A M, Roberts, B M And Kuznia, A. 2, 2016, International Journal Of Fashion Design, Technology And Education, Vol. 9, Pp. 142-152.

[16] Peningkatan Kreativitas Seni Dalam Desain Busana. Yuliati, Nanie Asri. 1, 2007, Jurnal Seni Dan Pendidikan Seni, Vol. 5, Pp. 173-184.

[17] Winda, Rianti.Eksplorasi Tenun Sambas Dengan Style Edgy Pada Busana Pesta. Bandung : Stisi Program Studi Kriya Tekstil Dan Mode, 2010.

[18] Upaya Peningkatan Export Drive Industri Fashion Di Era Globalisasi. Hadijah, Idah. 1, 2014, Jurnal Teknologi Dan Kejuruan, Vol. 37, Pp. 95108. 